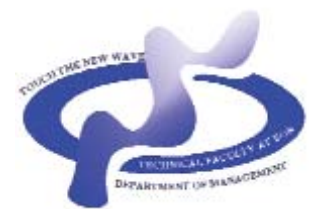

www.sjm06.com
Serbian

Journal

of

Management

\title{
AN EMPIRICAL EXAMINATION OF QUALITY TOOLS IMPACT ON FINANCIAL PERFORMANCES: EVIDENCE FROM SERBIA
}

\author{
Vesna Spasojević Brkića ${ }^{*}$, Tijana Đurđević b, Snežana Omić c \\ Milivoj Klarin ${ }^{d}$ and Nikola Dondur a \\ ${ }^{a}$ University of Belgrade, Faculty of Mechanical Engineering, Industrial Engineering \\ Department, Kraljice Marije 16, 11000 Belgrade, Serbia \\ $b_{\text {University of Alberta, Edmonton, Canada }}$ \\ ${ }^{c}$ Ministry of Education and Science, Belgrade, Serbia

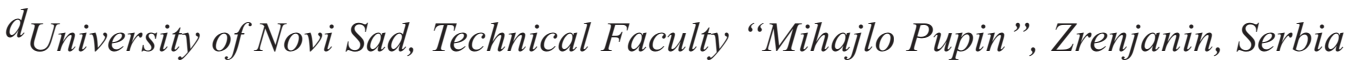

(Received 5 December 2011; accepted 12 January 2012)

\begin{abstract}
This study examines the impact of quality tools on financial performances using a sample of 119 Serbian industrial firms. Factor and reliability analysis are used to show that quality tools may be classified into three primary categories: quality tools for reviewing current conditions (for decision making), quality tools for analyzing current conditions (for problems solving) and quality tools for production planning and control (for improvement). The relationships between these 3 groups of quality tools and financial performances were tested using the stepwise regression analysis. It was concluded that the first group of quality tools (quality tools for reviewing current condition, e.g. for decision making) has significant impact on most of the dimensions of financial performances, while for the second and third group there is no statistical support. Influence of the first group of quality tools on sales revenue is statistically significant at a $\mathrm{p}<0.01$ significance level while it's influence on company profit and total revenue per employee are statistically significant at $\mathrm{p}<0.05$ significance level. The model ranged from $4 \%$ to $7 \%$.
\end{abstract}

Keywords: quality tools, financial performances, impact

\section{INTRODUCTION}

Even though quality tools and techniques improve the quality and overall business performance, little research has an empirical support for these relationships (Handfield, Jayaram \& Ghosh, 1999), so the problem of finding empirical support of these

\footnotetext{
* Corresponding author: vspasojevic@mas.bg.ac.rs
}

DOI: 10.5937/sjm1201077S 
relationships is a major driver for this research. Research was realized in two steps. First, all quality tools used were classified into groups using factor and reliability analysis. After that, relationships between the groups of quality tool factors, and financial performance measures (sales revenue, company profit and total revenue per employee) were tested using regression analysis. These relationships were tested through the sample of 119 Serbian industrial firms.

\section{LITERATURE REVIEW}

There is a certain number of researchers investigating in the field of quality tools (Handfield et al., 1999., Thia, Chai, Bauly \& Xin, 2005., Tari \& Sabater, 2004.). On the other hand, there is a small number of those who give an empirical support of the relationships between quality tools and business performance (Handfield, Jayaram \& Ghosh, 1999) . Furthermore, much of the literature concerned with measuring the impact of quality tools on performance of the firms is supported mainly by isolated cases (Handfield et al., 1999).

Handfield et al. (1999) analyze the impact of quality tools on business performance of the firms in order to find an empirical support of the relationships between them using a sample of 313 North American and European firms. By grouping quality tools into four classes, they have found the evidence that using some of the groups of quality tools has an impact on firm's performance, for example on market share. Conca, Tari and Sabater (2004) carry out an empirical study in order to verify the importance of quality tools and techniques for TQM improvement and their effect upon
TQM results using the answers provided by the person in charge of quality in 106 ISOcertified firms in Spain. The findings show that TQM tools and techniques are, with other critical factors, another important component of TQM, which emphasizes their importance for the improvement of TQM levels and results. A positive correlation has been found between these quality tools and techniques and the TQM level and TQM results of firms, and also that the firms with higher TQM levels and better results are those which most widely apply TQM tools and techniques. Alsaleh, (2007), examines the application of the quality tools in the production setups using a sample of 150 Saudi food industry companies and investigates some early signs of TQM implementation. The results show that there is a large percent of companies using quality tools and also that using those tools leads to performance improvement. Lagrosen and Lagrosen Y (2003), analyze the application of quality tools and techniques and its influence on the performance in different organizational models (Mintzberg's types of configurations). The results show that firms with adhocracy configuration use more quality tools and techniques then those with other 4 models of organization (simple structure, machine bureaucracy, professional bureaucracy, divisional form and adhocracy). Thia, Chai, Bauly and Xin (2005), investigate the reasons for adopting or nonadopting of quality tools in industry using a case study method, which has been found to be the most suitable for this kind of investigation. The results show that there are 2 groups of factors which affect the adoption of quality tools: internal and external factors. User-friendliness, usefulness, time, monetary cost, flexibility and popularity of the tools are internal factors which may 
influence the usage of tools. External factors are project nature, organization, industries and culture. On the other hand, Balbontin et al. (2000) has found that American companies tend to adopt more technologically inclined tools and techniques as compared to the their British counterparts. On the contrary, quality management tools are more highly adopted in British firms. Cristiano et al. (2000) compare the usage of QFD in American and Japanese firms and concluded that although QFD originated from Japan, it is used more frequently in American companies where more significant product and process improvements are also being derived from their usage. The central finding of Terziovski and Samson (2008) study is that ISO 9000 certification has a positive and significant effect on operational performance, but a positive weak effect on business performance. Measures of business performance were increased market share, improved corporate image, improved competitive advantage, increased access to global markets and increased organisations' profits.

Although many papers are published in this field of quality science, review of the literature shows necessity to investigate more in the field as this paper aims to.

\section{HYPOTHESIS FORMULATION}

Since this research attempts to address an investigation on the effect of quality tool deployment patterns on financial performances, laying mainly on Handfield et al. (1999) survey and trying to apply their ideas in Serbian industrial context, the following hypotheses have been formulated:

H1. Quality tools can be classified in small finite number of groups.
H2. Quality tools are related to the financial performance of the firms.

\section{METHODOLOGY}

\subsection{Survey instrument}

In order to obtain data needed for this study, the questionnaire a part of which was published in the study by Spasojević Brkić, et al. (2011), was used. For evaluation of using quality tools and business performance, Likert 5 point scale was used. In our questionnaire (shown in Appendix) 22 quality tools usually used in firms in our representative sample. Respondents needed to mark the value of using the certain tool on the scale 1 to 5 , while financial performance measures were sales revenue, company profit and total revenue per employee.

\subsection{Sample}

A large portion of the world economy, involving the countries of the former USSR, Bulgaria, Romania, Hungary, countries developed after dismemberment of former Yugoslavia, and Serbia as well are in the transition processes. That means that they are in phase of transformation of social into private ownership, introduction of new trade procedures and foreign investments in domestic companies, all demanding radical organizational changes conditioned by contextual ones in a new business ambient (Živković et al., 2009). Working in that kind of context, according to the Statistical Office of the Republic of Serbia (2010) there are 171484 companies in total in Serbia. According to the Business Registers Agency of Serbia (2010), there are $1164^{1}$ certified companies, until March of 2010 inclusive,

\footnotetext{
${ }^{1}$ Note that the number changes on a daily basis.
} 
which represent $1 \%$ of the total number of companies. The survey population consists of 969 certified companies that were represented with sufficient information in the Business Registers Agency of Serbia in order to be reached. Based on the experience of the other researchers, 250 industrial companies were chosen for the survey, including 40 large, 80 medium and 130 small companies (which corresponds to their proportion in the population), using the subjective method first and then checking with the Business Registers Agency of Serbia (by insight into their official public records on their website). Industrial companies (2000 exists in Serbia) were selected because the standard has originally been made for them (ISO 9000, 1994). Response was received from 119 companies, which comprises around $10 \%$ of Serbian industrial companies' population and shows a $47.6 \%$ response rate in this research. The following structure of sample companies has been obtained: 40\% large, 32\% medium and $28 \%$ small companies. The response was the lowest in small companies as there usually is more mature quality management practice in large and medium companies. The questionnaire has been answered by persons with 16.98 years of work experience on average, from which $41 \%$ quality department director, $32 \%$ directors of other technical departments, $22 \%$ employees in quality department or quality representatives and $5 \%$ other positions.

\section{RESULTS}

\subsection{Descriptive statistics}

Before analyzing the impact of quality tools on financial performance measures, descriptive statistics and correlations for all items have been done.

Table 1(a). Descriptive statistics of quality tool factors and financial performance measures

\begin{tabular}{|c|c|c|c|c|}
\hline Item & $\begin{array}{l}\text { Average } \\
\text { value }\end{array}$ & $\begin{array}{l}\text { Standard } \\
\text { deviation }\end{array}$ & Min & Max \\
\hline 1. Sales revenue & 3.77 & 1.071 & 1 & 5 \\
\hline 2. Company profit & 3.53 & 0.943 & 1 & 5 \\
\hline 3. Total revenue per employee & 3.35 & 0.922 & 1 & 5 \\
\hline $\begin{array}{l}\text { 4. Quality tools for Reviewing current condition } \\
\text { (for decision making) }\end{array}$ & 2.7803 & 1.33920 & 1 & 5 \\
\hline $\begin{array}{l}\text { 5. Quality tools for Analyzing current condition } \\
\text { (for problems solving) }\end{array}$ & 1.8546 & 1.01720 & 1 & 5 \\
\hline $\begin{array}{l}\text { 6. Quality tools for Production planning and } \\
\text { control (for improvement) }\end{array}$ & 2.0672 & 1.14152 & 1 & 5 \\
\hline
\end{tabular}

Table 1(b). Correlations for quality tool factors and financial performance items

\begin{tabular}{lllll}
1 & 2 & 3 & 4 & 5 \\
\hline
\end{tabular}

\begin{tabular}{|c|c|c|c|c|c|c|}
\hline 1. & Sales revenue & - & & & & \\
\hline 2. & Company profit & $0.648 * *$ & - & & & \\
\hline 3. & Total revenue per employee & $0.645 * *$ & $0.573 * *$ & - & & \\
\hline 4. & $\begin{array}{l}\text { Reviewing current condition } \\
\text { (for decision making) }\end{array}$ & $0.273^{* *}$ & $0.227^{*}$ & $0.213^{*}$ & - & \\
\hline 5. & $\begin{array}{l}\text { Analyzing current condition } \\
\text { (for problems solving) }\end{array}$ & $0.188^{* *}$ & 0.146 & 0.111 & $0.668^{* *}$ & - \\
\hline 6. & $\begin{array}{l}\text { Production planning and } \\
\text { control (for improvement) }\end{array}$ & 0.173 & 0.063 & 0.117 & $0.644 * *$ & $0.649 * *$ \\
\hline
\end{tabular}

** Significant at 0.01

* Significant at 0.05 
In table 1(a), the descriptive statistics (mean, standard deviations, minimum and maximum values) for the three quality tool groups and financial performance measures (sales revenue, company profit and total revenue per employee) are presented. Table 1(b) shows the correlations of the financial performance (sales revenue, company profit and total revenue per employee) with the three quality tool groups (quality tools for reviewing current condition (for decision making), quality tools for analyzing current condition (for problems solving) and quality tools for production planning and control (for improvement)). As can be seen from this table, all financial performance measures are mutually correlated at a $\mathrm{p}<0.01$ significance level.

\subsection{Reliability of the measure}

Reliability testing was done through Cronbach's alpha coefficient calculation, where coefficient's value of 1 means the perfect reliability and values 0.70 are acceptable (Hair, Anderson, Tatham, \& Black, 1998). In Table 2, reliabilities of items for the three quality tool factors are presented.

\subsection{Testing of hypothesis using factor analysis and stepwise regression analysis}

The stated hypothesis were tasted using factor, reliability and stepwise regression analysis. The first hypothesis H1 (Quality tools can be classified in small finite number of groups), was tested by factor analysis, and the second hypothesis $\mathrm{H} 2$ using the stepwise regression analysis. For stepwise regression analysis, the three groups of quality tools obtained in factor analysis were used as the independent variable, while financial performances (sales revenue, company profit and total revenue per employee) were used as the dependent variable.

Table 2. Reliabilities of items for the three quality tool factors

\begin{tabular}{lccc}
\hline \multicolumn{1}{c}{ Factor, with items } & $\begin{array}{c}\text { Corrected } \\
\text { item-total } \\
\text { correlation }\end{array}$ & $\begin{array}{c}\text { Cronbach's } \\
\text { alpha }\end{array}$ & $\begin{array}{c}\text { Cronbach's } \\
\text { alpha if } \\
\text { item is } \\
\text { deleted }\end{array}$ \\
\hline Reviewing current condition (for decision making) & 0.776 & 0.901 & 0.876 \\
Form for collecting data & 0.791 & & 0.874 \\
Team work & 0.780 & & 0.876 \\
Incoming, process and outcoming inspection & 0.597 & & 0.902 \\
Internal audit & 0.702 & & 0.887 \\
Electronic document management & 0.734 & & 0.883 \\
Data processing and analysis & & 0.904 & \\
Analyzing current condition (for problems solving) & 0.754 & & 0.887 \\
Histogram & 0.684 & & 0.894 \\
Control charts & 0.708 & & 0.891 \\
Pareto charts & 0.694 & & 0.892 \\
Cause-effect diagram & 0.652 & & 0.896 \\
Brainstorming & 0.744 & & 0.887 \\
Benchmarking & 0.724 & & 0.892 \\
FMEA & 0.662 & & 0.896 \\
Acceptance-sampling methods & & \multirow{2}{*}{0.855} & \\
Production planning and control (for improvement) & 0.606 & & 0.842 \\
Stratification & 0.648 & & 0.830 \\
Network analysis & 0.685 & & 0.821 \\
Value analysis & 0.713 & & 0.813 \\
Study of precision, accuracy and process stability & 0.707 & & 0.814 \\
Reliability analysis & & \\
\hline
\end{tabular}




\subsubsection{Hypothesis 1}

The results for testing the first hypothesis are shown in Table 3. An explorative factor analysis using principal components with varimax rotation was conducted on the set of 22 quality tools. Only factors that accounted for variances greater the one i.e. with eigenvalues $>1$ were extracted. As can be seen from Table 3, three factors were extracted that accounted for $64,46 \%$ of the total variation in the observed variables. Table 3 shows the total and the cumulative variance for each extracted factor as well.

For interpreting the factors and sample size of 119, only items which had factor loadings grater than 0.5 were included (Hair et al., 1998). Those values are bold in the Table 3 . The resulting three factors may be interpreted as the following:

1. Quality tools for reviewing current condition (for decision making): Form for collecting data, Team work, Incoming, process and outcoming inspection, Internal audit, Electronic document management, Data processing and analysis.

2. Quality tools for analyzing current condition (for problems solving): Histogram, Control charts, Pareto chart, Cause-effect diagram, Brainstorming, Benchmarking, FMEA, Acceptance-sampling methods.

3. Quality tools for production planning and control (for improvement): Stratification, Network analysis, Value

Table 3. Rotated factor loading for the three quality tool factors

\begin{tabular}{|c|c|c|c|}
\hline Variables & $\begin{array}{c}\text { Factor } 1 \\
\text { (Reviewing } \\
\text { current } \\
\text { condition } \\
\text { /for } \\
\text { decision } \\
\text { making) }\end{array}$ & $\begin{array}{c}\text { Factor } 2 \\
\text { (Analyzing } \\
\text { current } \\
\text { condition } \\
\text { /for } \\
\text { problems } \\
\text { solving) }\end{array}$ & $\begin{array}{c}\text { Factor } 3 \\
\text { (Production } \\
\text { planning and } \\
\text { control / for } \\
\text { improvement) }\end{array}$ \\
\hline Form for collecting data & 0.720 & 0.283 & 0.320 \\
\hline Histogram & 0.230 & 0.761 & 0.215 \\
\hline Control charts & 0.378 & 0.579 & 0.330 \\
\hline Stratification & 0.077 & 0.491 & 0.617 \\
\hline Team work & 0.820 & 0.151 & 0.226 \\
\hline Incoming, process and outcoming inspection & 0.822 & 0.173 & 0.187 \\
\hline Quality costs analysis & 0.496 & 0.178 & 0.457 \\
\hline QFD & 0.004 & 0.624 & 0.525 \\
\hline Pareto charts & 0.200 & 0.733 & 0.184 \\
\hline Cause-effect diagram & 0.198 & 0.614 & 0.447 \\
\hline Brainstorming & 0.425 & 0.641 & 0.059 \\
\hline Flow chart & 0.540 & 0.285 & 0.549 \\
\hline Network analysis & 0.159 & 0.188 & 0.781 \\
\hline Internal audit & 0.598 & 0.394 & 0.124 \\
\hline Benchmarking & 0.337 & 0.750 & 0.120 \\
\hline Electronic document management & 0.715 & 0.216 & 0.282 \\
\hline FMEA & 0.094 & 0.759 & 0.335 \\
\hline Acceptance-sampling methods & 0.482 & 0.600 & 0.111 \\
\hline Data processing and analysis & 0.767 & 0.228 & 0.197 \\
\hline Value analysis & 0.377 & 0.157 & 0.688 \\
\hline Study of precision, accuracy and process stability & 0.340 & 0.278 & 0.669 \\
\hline Reliability analysis & 0.412 & 0.178 & 0.680 \\
\hline Eigenvalue & 10.759 & 1.967 & 1.457 \\
\hline Percentage of variance explained & 48.905 & 8.939 & 6.621 \\
\hline $\begin{array}{l}\text { Cumulative proportion of total variance } \\
\text { explained }\end{array}$ & 48.905 & 57.844 & 64.465 \\
\hline
\end{tabular}


analysis, Study of precision, Accuracy and process stability, Reliability analysis.

This way, the first hypothesis $\mathrm{H} 1$ that states that quality tools can be classified in small finite number of groups is confirmed. The results from table 3 indicate that there are three finite groups where quality tools may be classified: Quality tools for reviewing current condition (for decision making), quality tools for analyzing current condition (for problems solving) and quality tools for production planning and control (for improvement).

\subsubsection{Hypothesis 2}

Hypothesis 2 posits a relationship between the three quality tool factors and financial performance: sales revenue, company profit and total revenue per employee. The results of stepwise regression analysis are shown in table 4. Table 4 represents the model $\boldsymbol{R}^{2}$, F-value, p-value and values of standardized and unstandardized coefficient $\beta$.

The results of stepwise regression analysis (Table 4) showed that only the quality tools for reviewing current condition (for decision making) have an important influence ( $\mathrm{p}<0.05$ or 0.01$)$ on all financial performance measures (sales revenue, company profit and total revenue per employee). The other two groups of quality tools - quality tools for analyzing current condition and quality tools for improvement - have no impact on financial performance and this is why they are not included in table 4. The results also confirm the correlations which exist between these variables. Sales revenue is statistically significant at a $p<0.01$ significance level. Company profit and total revenue per employee are statistically significant at $\mathrm{p}<0.05$ significance level. The model $\mathrm{R}^{2}$ ranged from $4 \%$ to $7 \%$. Very small, but significant values on 0.01 level of $\mathrm{R}^{2}$ around $4 \%$ are obtained for company profit and total revenue per employee and they show week influence of quality tools. Influence of quality tools is even less significant on sales revenue, although it has higher value $(7 \%)$. Conclusion is that quality tools are weak, but one of predictors of financial performances in Serbia. According to our survey quality tools application is recommended in that sense and companies can increase their financial performances with quality tools usage in some extent. But, given the low value of $\mathrm{R}^{2}$, the results also

Table 4. Stepwise regression results of financial performances versus quality tool factors

\begin{tabular}{|c|c|c|c|c|c|}
\hline $\begin{array}{l}\text { Dependent variable, } \\
\text { with independent } \\
\text { variables }\end{array}$ & $\begin{array}{c}\text { Model } \\
\boldsymbol{R}^{2}\end{array}$ & $\begin{array}{c}F- \\
\text { value }\end{array}$ & $\begin{array}{c}P- \\
\text { value }\end{array}$ & $\begin{array}{c}\text { Variables } \\
\text { Standardized }\end{array}$ & $\frac{\text { Entered }}{\text { Unstandardized }}$ \\
\hline $\begin{array}{l}\text { Sales revenue } \\
\text { Reviewing current condition } \\
\text { (for decision making) }\end{array}$ & 0.071 & 8.929 & $\begin{array}{l}0.003 * * \\
0.003 * *\end{array}$ & 0.266 & 0.209 \\
\hline $\begin{array}{l}\text { Company profit } \\
\text { Reviewing current condition } \\
\text { (for decision making) }\end{array}$ & 0.049 & 6.066 & $\begin{array}{l}0.015^{*} \\
0.015^{*}\end{array}$ & 0.222 & 0.153 \\
\hline $\begin{array}{l}\text { Total revenue per employee } \\
\text { Reviewing current condition } \\
\text { (for decision making) }\end{array}$ & 0.043 & 5.285 & $\begin{array}{l}0.023^{*} \\
0.023^{*}\end{array}$ & 0.208 & 0.140 \\
\hline
\end{tabular}


must be interpreted with some caution and should be checked in some future surveys.

\section{CONCLUSION}

This study comes to conclusion that it is possible to classify the considered tools into a smaller, finite number of groups. In Serbian industrial context the quality tools have been classified into three groups: quality tools for reviewing current condition (for decision making), quality tools for analyzing current condition (for problems solving) and quality tools for production planning and control (for improvement). Quality tools classification can serve as pattern of usage in practice. Important conclusion is also the fact that only quality tools for reviewing current condition (for decision making) have an important impact on all financial performance measures, so there comes an recommendation to use them more if company wants to improve its financial performances.

The findings obtained in this study can be compared to the findings of Handfield's (1999) examination study, where the authors have found that there are 4 groups of quality tools, in the North-American context. Similar to this study, the influence of obtained groups of quality tools has been tested using regression analysis. In their work the obtained values of coefficient of determination were relatively low, while the influence of certain groups of quality tools on some of the business performance measures were even negative. In this study, the values of coefficient $\beta$ were positive in all cases, so it can be concluded that using the first quality tools group deployment leads to improvement of financial performance measures. On the other hand, there is no statistical support of the relationships between financial performance and the second and the third group of quality tools. Further analysis of influence of those groups on other types of performance is an idea for future research.

The limitation of this study is the fact that this research is a cross sectional study. Proposition for future research is longitudinal study and using the structural equation modeling (SEM), which these days draws attention of a large number of researches.

Acknowledgement: The paper is supported by grants from the Serbian Ministry of Science under contracts TR 35017. 


\title{
ЕМПИРИЈСКО ИСТРАЖИВАЮЕ УТИЦАЈА АЛАТА КВАЛИТЕТА НА ФИНАНСИЈСКЕ ПОКАЗАТЕЉЕ: ПРИМЕР ИЗ СРБИЈЕ
}

\author{
Весна Спасојевић Бркић ${ }^{\mathbf{a}^{*}}$, Тијана Ђурђевић ${ }^{\mathrm{b}}$, Снежана Омићс, \\ Миливој Кларин ${ }^{d}$ и Никола Дондур ${ }^{a}$

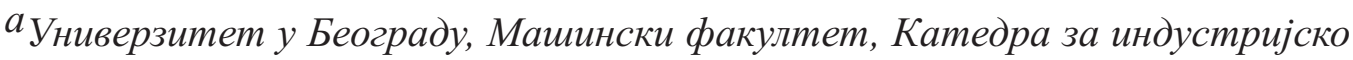 \\ инжењерство, Краљиие Марије 16, 11000 Београд, Србија \\ $b_{\text {University of Alberta, Edmonton, Canada }}$ \\ ${ }^{c}$ Министарство образовања и науке, Београд, Србија

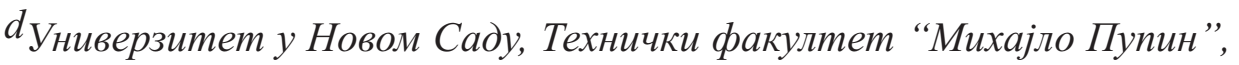 \\ Зрењанин, Србија
}

Извод

Ова студија истражује утицај алата квалитета на финансијске показатеље, при истраживању на узорку од 119 Српских индустријских предузећа. Факторском анализом и анализом поузданости доказано је да се алати квалитета могу класификовати у у три примарне категорије: алати квалитета за преглед тренутних услова (за одлучивање), алати квалитета за анализу тренутних услова (за решавање проблема) и алати квалитета за планирање производње и контролу (за унапређење). Односи између ове 3 групе алата квалитета и финансијских показатеља тестиранису употребом "stepwise" регресионе анализе. Закључено је да прва група алата квалитета (за одлучивање) има значајни утицај на већину димензија финансијских перформанси, док друга и трећа група немају статистичку значајност. Утицај прве групе алата квалитета на приход од продаје је са нивоом статистичке значајности $\mathrm{p}<0.01$ док је њен утицај на профит компаније и укупне приходе по запосленом статистичког значаја p $<0.05$. Конзистенција моидела је била у рангу $4 \%$ до 7\%.

Кључне речи: алати квалитета, финансијске перформансе, утицај

\section{References}

Alsaleh, N. (2007) Application of quality tools by the Saudi food industry. The TQM Magazine, 19(2):150-161.

Balbontin, A., Yazdani, B.B., Cooper, R., \& Souder, W.E. (2000) New product development practices in American and British firms. Journal of Production Innovation Management, 20: 257-74.

Business Registers Agency of Serbia (2010),http://www.pks.rs/Default.aspx?tabid $=2315$
Conca, F., Llopis, J., \& Tari, J. (2004) Development of a measure to assess quality management in certified firms. European Journal of Operational Research, 156: 683697.

Cristiano, J.J., Liker, J.K., \& White, C.C. (2000) Customer-driven product development through quality function deployment in the US and Japan. Journal of Product Innovation Management, 17: 286308.

Hair, J., Anderson, R., Tatham, R., \& Black, W. (1998). Multivariate data analysis, 
New York, USA: Prentice Hall.

Handfield, R., Jayaram, J., \& Ghosh, S. (1999) An empirical examination of quality tool deployment patterns and their impact on performance. International Journal of Production Research, 37(6): 1403-1426.

Lagrosen, S., \& Lagrosen, Y. (2003) Quality configurations: a contingency approach to quality management. International Journal of Quality \& Reliability Management, 20(7): 759-773.

Statistical Office of the Republic of Serbia (2010) Statement, LX (9), http://pod2.stat.gov.rs/ObjavljenePublikacije /G2010/pdf/G20101009.pdf

Spasojević Brkić, V. (2009), Contingency Theory and Quality Management, University of Belgrade, Belgrade: Faculty of Mech. Eng (in Serbian).

Spasojević Brkić, V., Klarin, M.M., Brkić, A.Dj., Lučanin, V.J., \& Milanović, D.D. (2011), Simultaneous consideration of contingency factors and quality management: An empirical study of Serbian companies. African Journal of Business Management. 5(3):866-883.

Tari, J., \& Sabater, V. (2004) Quality tools and techniques: Are they necessary for quality management?. International Journal of Production Economics, 92:267-280.

Terziovski, M., \& Samson, D. (2008) Relationship of ISO 9001:2000 quality system certification with operational and business performance: A survey in Australia and New Zealand-based manufacturing and service companies. Journal of Manufacturing Technology Management, 19(1):22-37.

Thia, C., Chai, K., Bauly, J., \& Xin, Y. (2005) An exploratory study of the use of quality tools and techniques in product development. The TQM Magazine, 17(5): 406-424.

Živković, Ž., Mihajlović, I., Prvulović, S.
(2009) Developing motivation model as a strategy for HRM in small enterprises under transitional economy. Serbian Journal of Management, 4(1): 1-27. 
Appendix: The Questionnaire used for conducting the survey

\section{Company profile}

1. Number of employees is

2. Year of company foundation

3. Company operates in sector.

4. Company posses ISO 9000 certificate. Yes No

5. Year of the first certification according to ISO 9000

6. I work in department on position of and have years of work experience.

\section{Quality tools application}

Whether and to what extent you use the following methods and techniques to improve quality:

\begin{tabular}{|l|lllll|}
\hline $\begin{array}{l}\text { Methods and techniques to improve quality } \\
\text { Quality Tools Application }\end{array}$ & \multicolumn{5}{|l|}{$\begin{array}{l}\text { Round off the } \\
\text { scope }\end{array}$} \\
\hline Check list & 1 & 2 & 3 & 4 & 5 \\
\hline Histogram & 1 & 2 & 3 & 4 & 5 \\
\hline Control chart & 1 & 2 & 3 & 4 & 5 \\
\hline Stratification & 1 & 2 & 3 & 4 & 5 \\
\hline Team work & 1 & 2 & 3 & 4 & 5 \\
\hline Iinput, process and output inspection & 1 & 2 & 3 & 4 & 5 \\
\hline Analysis of quality costs & 1 & 2 & 3 & 4 & 5 \\
\hline QFD & 1 & 2 & 3 & 4 & 5 \\
\hline Pareto diagram & 1 & 2 & 3 & 4 & 5 \\
\hline Cause-Effect Diagram & 1 & 2 & 3 & 4 & 5 \\
\hline Brainstorming & 1 & 2 & 3 & 4 & 5 \\
\hline Flowchart & 1 & 2 & 3 & 4 & 5 \\
\hline Network Plan (CPM/PERT) & 1 & 2 & 3 & 4 & 5 \\
\hline Internal Audit & 1 & 2 & 3 & 4 & 5 \\
\hline Benchmarking & 1 & 2 & 3 & 4 & 5 \\
\hline Electronic Control of documentation & 1 & 2 & 3 & 4 & 5 \\
\hline FMEA & 1 & 2 & 3 & 4 & 5 \\
\hline Sampling and acceptance methods & 1 & 2 & 3 & 4 & 5 \\
\hline $\begin{array}{l}\text { Analysis and processing of data (complaints, } \\
\text { conflicts, etc.). }\end{array}$ & 1 & 2 & 3 & 4 & 5 \\
& & & & & \\
\hline Value analysis & & & & & \\
\hline $\begin{array}{l}\text { Study of precision, accuracy and stability of } \\
\text { the process }\end{array}$ & 1 & 2 & 3 & 4 & 5 \\
\hline Reliability Analysis & 1 & 2 & 3 & 4 & 5 \\
\hline$* *$ & 1 & & & & \\
\hline & 1 & 2 & 3 & 4 & 5 \\
\hline & 1 & 2 & 3 & 4 & 5 \\
\hline
\end{tabular}

* (1 - not used, 5 - full range of applications that significantly improves quality)

** If you use some other methods and techniques to improve quality, that are not listed in the table, enter here a name and mark the extent.

\section{Financial performance measures}

\begin{tabular}{|l|lllll|l|}
\hline \multicolumn{1}{|c|}{ Financial performance measures (Round off the value) } \\
\hline Sales revenue is rapidly decreasing & 1 & 2 & 3 & 4 & 5 & Sales revenue is rapidly increasing \\
\hline Company profit is rapidly decreasing & 1 & 2 & 3 & 4 & 5 & Company profit is rapidly increasing \\
\hline Total revenue per employee decreases rapidly & 1 & 2 & 3 & 4 & 5 & Total revenue per employee is growing rapidly \\
\hline
\end{tabular}

